\title{
A STUDY OF FOUR CASES WITH KLINEFELTER'S SYNDROME, SHOWING MOTILE SPERMATOZOA IN THEIR EJACULATES
}

\author{
G. L. FOSS AND F. J. W. LEWIS \\ Endocrine Clinics, United Bristol Hospitals, \\ and Male Subfertility Clinic, Bristol, \\ and Department of Pathology, Southmead Hospital, Bristol
}

(Received 21st fuly 1970)

\begin{abstract}
Summary. Four unusual cases of Klinefelter's syndrome are described, in which motile spermatozoa were found in several ejaculates. One of these subjects was shown to be a $47 \mathrm{XXY} / 46 \mathrm{XY}$ mosaic, but intensive cytogenic studies in the other three failed to reveal evidence of this. Records of proven parenthood may eventually disturb the present concept of sterility in this condition.
\end{abstract}

\section{INTRODUCTION}

Since the original description of this syndrome by Klinefelter, Reifenstein \& Albright (1942), it has become evident that the clinical findings and the testicular histology show considerable variations. There is also a wide range of karyotypes reported in the literature (46XY, 47XXY, 48XXYY, 48XXXY, $49 \mathrm{XXXYY}, 49 \mathrm{XXXXY}$, and various mosaics- $\mathrm{XX} / \mathrm{XXY}, \mathrm{XY} / \mathrm{XXY}$, $\mathrm{XY} / \mathrm{XXXY}, \mathrm{XXXY} / \mathrm{XXXXY}, \mathrm{XY} / \mathrm{XXY} / \mathrm{XXXY}, \mathrm{XxY} / \mathrm{Xx} / \mathrm{XY}$ ).

In cases of apparent $47 X X Y$ karyotype, small areas of seminiferous tubules showing complete spermatogenesis have been reported in some biopsies (Steinberger, Smith \& Perloff, 1965; Foss, Bell, Lewis, Loraine \& Pollard, 1967). These same subjects, however, had complete azoospermia, although Foss $\mathrm{et}$ al. (1967) reported the production of motile spermatozoa in several ejaculates in the patient after treatment with clomiphene.

Futterweit (1967) described a 29-year-old man with a 47XXY karyotype in the cells of the peripheral blood, who had spermatozoa in five seminal specimens with counts varying from a few up to $2 \times 10^{6}$ spermatozoa $/ \mathrm{ml}$, but motile spermatozoa were only seen in two specimens. This is possibly a more frequent occurrence than was originally believed.

During the last 4 years, 466 new patients have attended the Bristol Infertility Clinic and fifteen have been shown to have Klinefelter's syndrome with a karyotype of $47 \mathrm{XXY}$ in leucocyte cultures-an incidence of $3.2 \%$. Four of these patients who had motile spermatozoa in their ejaculates on several occasions form the subject of this study. 


\section{MATERIAL AND METHODS}

Seminal analyses were carried out in three different laboratories. Collections were made, on waking, by masturbation into plastic containers and were examined within $3 \mathrm{hr}$. The specimens were obtained at an interval after coitus equivalent for the individual to that between normal acts of intercourse.

Testicular biopsies were obtained in the out-patient theatre, under general anaesthesia by the open method (Foss, 1968). Specimens were fixed in Bouin's solution, and sections of $5 \mu \mathrm{m}$ were stained by haematoxylin and eosin and Masson's trichrome.

\section{Cytogenetics}

All four cases had examinations of buccal smears and chromosome analyses on cultures of leucocytes and fibroblasts, using the method of Moorhead, Nowell, Mellman, Battips \& Hungerford (1960). The fibroblast cultures were obtained from skin in two patients and from testes in the other two. In addition, drumstick counts were made on leucocytes from three of the patients.

Serial 24-hr urine collections were made before and during clomiphene

TABLE 1

GLINIGAL DETAILS OF FOUR GASES OF KLINEFELTER'S SYNDROME PRODUCING LIVE SPERMATOZOA

\begin{tabular}{|c|c|c|c|c|c|c|c|c|}
\hline Patient & $\begin{array}{c}\text { First } \\
\text { seen }\end{array}$ & Occupation & $\begin{array}{c}\text { Secondary } \\
\text { sex } \\
\text { characters }\end{array}$ & $\begin{array}{l}\text { Testes } \\
\left(\mathrm{cm}^{3}\right)\end{array}$ & $\begin{array}{c}H t \\
(\mathrm{~cm})\end{array}$ & $\begin{array}{c}W t \\
(k g)\end{array}$ & $\begin{array}{l}\text { Gynaeco- } \\
\text { mastia }\end{array}$ & Karyotype \\
\hline A.W. & 1965 & $\begin{array}{l}\text { Planning } \\
\text { engineer }\end{array}$ & $\mathrm{N}$ & $\begin{array}{c}1.5 \\
\text { both }\end{array}$ & $180 \cdot 3$ & $98 \cdot 4$ & Slight & $47 X X Y$ \\
\hline P.T. & 1968 & $\begin{array}{l}\text { Furniture } \\
\text { maker }\end{array}$ & $\mathbf{N}$ & $\begin{array}{c}2 \cdot 0 \\
\text { right }\end{array}$ & $177 \cdot 8$ & $73 \cdot 0$ & Nil & $47 X X Y$ \\
\hline $\mathbf{F x}$ & 1968 & $\begin{array}{l}\text { Agricultural } \\
\text { engineer }\end{array}$ & $\mp$ & $\begin{array}{c}2 \cdot 5 \\
\text { both }\end{array}$ & $177 \cdot 8$ & $79 \cdot 3$ & Slight & $47 X X Y$ \\
\hline D.G. & 1968 & Storekeeper & $\mp$ & $\begin{array}{c}2 \cdot 5 \\
\text { both }\end{array}$ & $181 \cdot 6$ & $85 \cdot 7$ & Nil & $\underset{46 X Y}{47 X X Y}$ \\
\hline
\end{tabular}

$$
\left.\begin{array}{rl}
\text { A.W. } & =\text { Patient } 4 \\
\text { P.T. } & =\text { Patient } 3 \\
\text { D.G. }=\text { Patient } 2
\end{array}\right\} \text { Adamopoulos et al. (1971). }
$$

treatment and also after its withdrawal. Urine was sent deep-frozen to Edinburgh, and the results of three cases are reported separately (Adamopoulos, Loraine, Ismail \& Foss, 1971). All four patients when first seen were aged 30 years, and their clinical details are shown in Table 1 . The testes were measured in $\mathrm{cm}^{3}$ by a testimeter (Foss et al., 1967).

\section{EXPLANATION OF PLATE 1}

Fig. 1. A.W. Solitary tubule with thickened wall and absent spermatogenesis: Leydig cell hyperplasia. H \& E, $\times 500$.

FIG. 2. P.T. Thick-walled tubule with no definite evidence of spermatogenesis. H \& E, $\times 500$.

Fig. 3. Fx. Thick-walled tubule with cellular content and some spermatogenesis. H \& E, $\times 500$.

FIG. 4. D.G. Thin-walled tubule showing full range of spermatogenic cells. H \& E, $\times 500$. 
PI $\triangle$ TTE 1

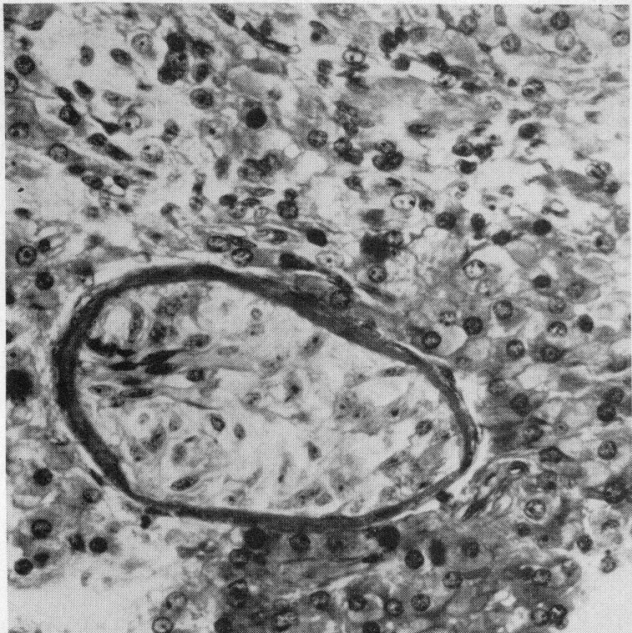

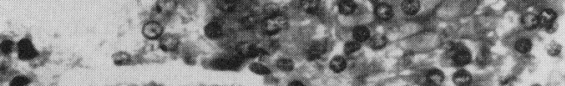

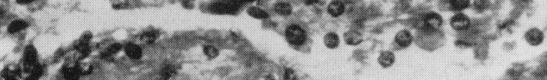
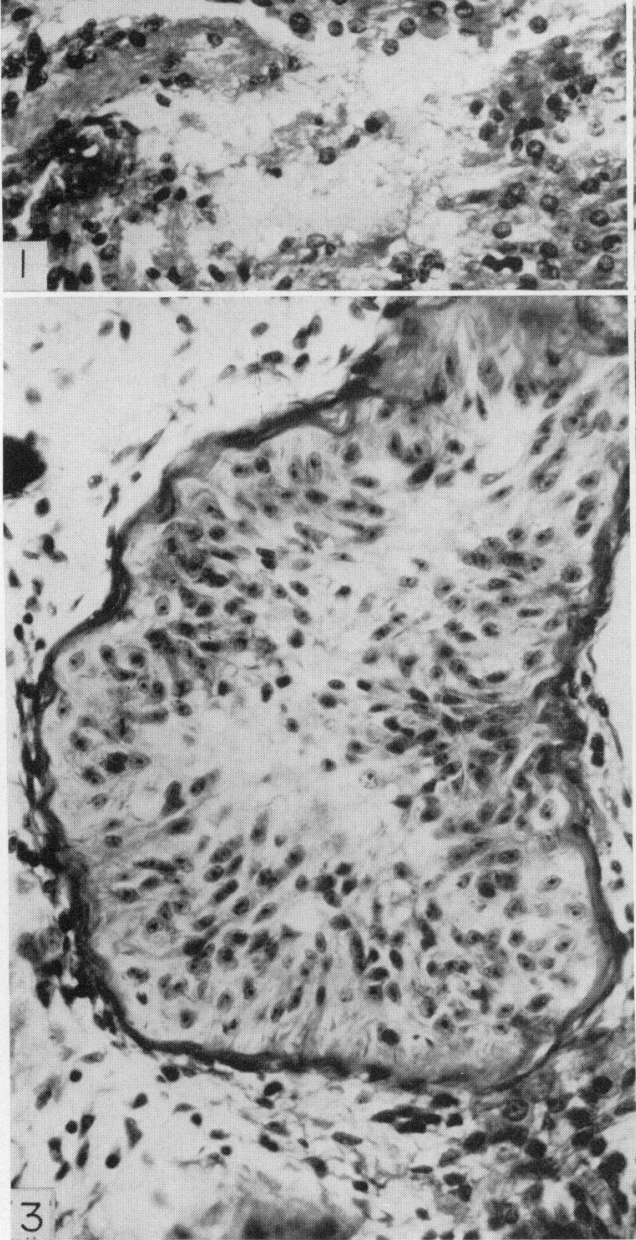

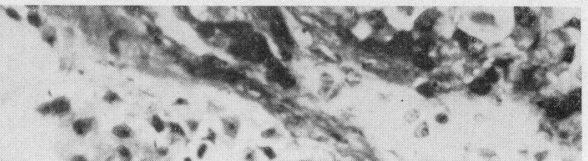
$-30^{\prime}, \div=30$

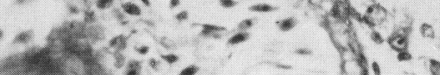

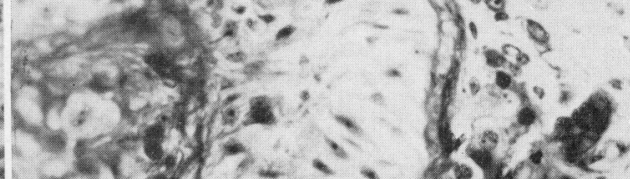

$3 x^{2}+2=$

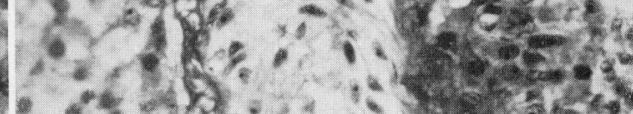

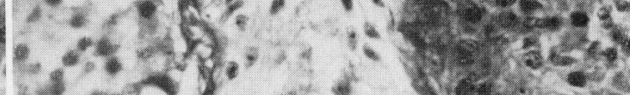

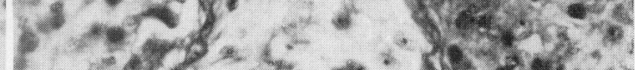

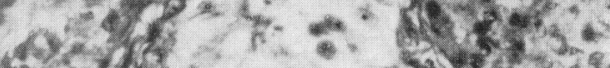

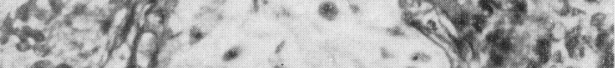

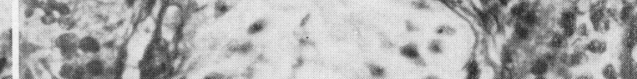

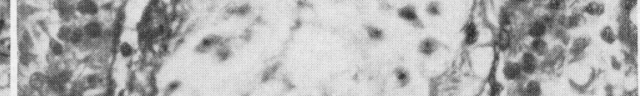

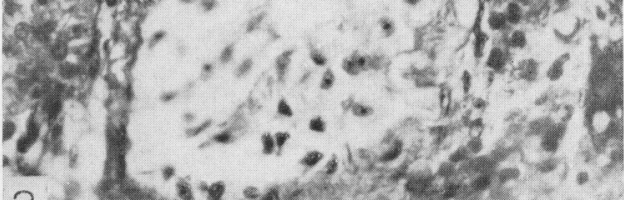

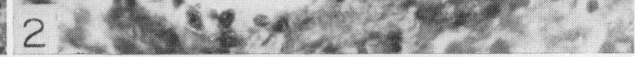



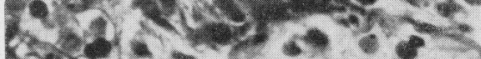

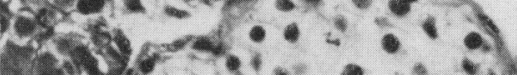

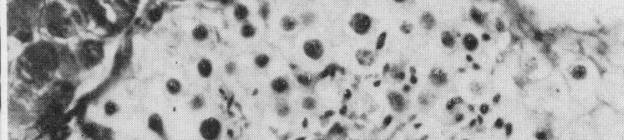

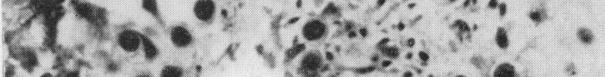
C.3. - a S. If 20 T: $=0$

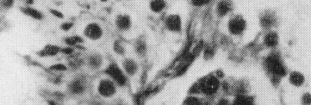

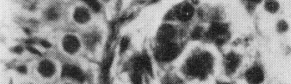
- al (a)

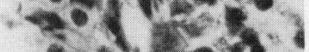
C) -8 $\because \pm 1+10-1$.

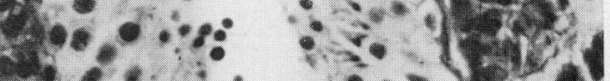


q

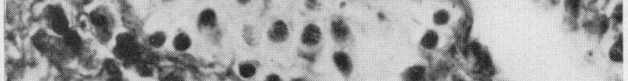

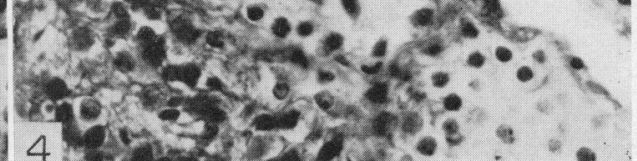

(Facing p. 402) 


\section{RESULTS}

Seminal analyses and the response of the four patients to a short course of clomiphene are shown in Tables 2, 3, 4 and 5. The testicular histology is depicted in Pl. 1, Figs. 1, 2, 3 and 4. In only one patient, D.G. (Pl. 1, Fig. 4), was the whole range of the spermatogenic series apparent in one tubule. Cytogenetic studies are recorded in Tables 6 and 7.

TABLE 2

SEMINAL ANALYSES FOR PATIENT A.W.

\begin{tabular}{|c|c|c|c|c|}
\hline Date & $\begin{array}{r}V o l \\
(m l)\end{array}$ & $\begin{array}{l}\text { Sperm count } \\
\left(\times 10^{6} / \mathrm{ml}\right)\end{array}$ & $\underset{(\%)}{M o t i l i t y}$ & \\
\hline $\begin{array}{l}\text { Dec. } 64 \\
12.1 .65\end{array}$ & $\underset{3.5}{(3 \mathrm{SA}})^{*}$ & $\begin{array}{l}\text { Scanty } \\
-\end{array}$ & - & \\
\hline $\begin{array}{l}15.4 .69 \\
22.4 .69\end{array}$ & $\begin{array}{l}2 \cdot 0 \\
2 \cdot 0\end{array}$ & $\begin{array}{l}0.2 \\
2 \cdot 0\end{array}$ & $\begin{array}{r}1 \\
10\end{array}$ & $\begin{array}{l}\text { Clomiphene } 100 \mathrm{mg} / \text { day from } \\
\text { 10th April for } 14 \text { days }\end{array}$ \\
\hline $\begin{array}{r}29.4 .69 \\
6.5 .69 \\
13.5 .69 \\
20.5 .69\end{array}$ & $\begin{array}{l}1.8 \\
3.0 \\
1.5 \\
2.0\end{array}$ & $\begin{array}{c}4 \cdot 0 \\
\text { Scanty } \\
0.2 \\
0.2\end{array}$ & $\frac{15}{-}$ & \\
\hline
\end{tabular}

* Three seminal analyses before participating in this study.

TABLE 3

SEMINAL ANALYSES FOR PATIENT P.T.

\begin{tabular}{|c|c|c|c|c|}
\hline Date & $\begin{array}{c}V o l \\
(m l)\end{array}$ & $\begin{array}{l}\text { Sperm count } \\
\left(\times 10^{6} / m^{l}\right)\end{array}$ & $\begin{array}{c}\text { Motility } \\
(\%)\end{array}$ & \\
\hline $\begin{array}{c}28.5 .68 \\
4.6 .68 \\
11.6 .68 \\
10.9 .68 \\
17.9 .68 \\
24.9 .68 \\
1.10 .68 \\
8.10 .68 \\
15.10 .68 \\
22.10 .68 \\
27.2 .69\end{array}$ & $\begin{array}{l}2 \cdot 0 \\
1 \cdot 5 \\
2 \cdot 0 \\
2 \cdot 2 \\
2 \cdot 4 \\
1 \cdot 4 \\
1 \cdot 4 \\
2 \cdot 0 \\
2 \cdot 0 \\
1 \cdot 8 \\
2 \cdot 0\end{array}$ & $\begin{array}{c}3.0 \\
- \\
10 \cdot 0 \\
4 \cdot 0 \\
\text { Scanty } \\
\overline{4 \cdot 0} \\
24 \cdot 0 \\
8 \cdot 0 \\
\text { Scanty }\end{array}$ & $\begin{array}{l}10 \\
\overline{-} \\
10 \\
65 \\
\overline{2} \\
50 \\
10 \\
-\end{array}$ & \\
\hline $\begin{array}{r}4.3 .69 \\
11.3 .69\end{array}$ & $\begin{array}{l}2 \cdot 0 \\
2 \cdot 0\end{array}$ & - & - & $\begin{array}{l}\text { Clomiphene } 100 \mathrm{mg} / \text { day from } \\
\text { Ist March for } 14 \text { days }\end{array}$ \\
\hline 18.3 .69 & $2 \cdot 0$ & - & $\ldots$ & \\
\hline
\end{tabular}

\section{DISCUSSION}

In testicular biopsies from men with Klinefelter's syndrome, the occasional finding of nests of seminiferous tubules with complete spermatogenesis has been reported, but only on rare occasions have spermatozoa been demonstrated in the ejaculate. Warburg (1963) reported a "total sperm count" of 
200,000 in a 40-year-old man, who, 6 months later, was shown to have a $47 \mathrm{XXY} / 46 \mathrm{XY}$ mosaic.

Futterweit (1967) described one man aged 29 years, with five reported sperm counts ranging from a few spermatozoa/ejaculate to $2 \times 10^{6}$ spermatozoa/ $\mathrm{ml}$, with occasional motile forms in two specimens. The karyotype, on the peripheral blood only, was $47 \mathrm{XXY}$.

TABLE 4

SEMINAL ANALYSES FOR PATIENT FX

\begin{tabular}{|c|c|c|c|c|}
\hline Date & $\begin{array}{c}V o l \\
(m l)\end{array}$ & $\begin{array}{l}\text { Sperm count } \\
\left(\times 10^{6} / \mathrm{ml}\right)\end{array}$ & $\begin{array}{c}\text { Motility } \\
(\%)\end{array}$ & \\
\hline $\begin{array}{l}14.6 .67 \\
28.6 .67 \\
16.8 .67 \\
29.867 \\
12.9 .67 \\
19.9 .67 \\
27.967 \\
10.10 .67 \\
17.10 .67 \\
244.10 .67 \\
31.10 .67\end{array}$ & $\begin{array}{l}2 \cdot 6 \\
3.8 \\
2 \cdot 6 \\
2.5 \\
4.0 \\
5.0 \\
5.5 \\
4.0 \\
5.0 \\
4.5 \\
4.2 \\
\end{array}$ & $\begin{array}{c}\text { Occasional } \\
3.0 \\
2.0 \\
= \\
\overline{1.0} \\
\bar{Z} \\
\overline{2.0} \\
1.0 \\
1.0 \\
\end{array}$ & $\begin{array}{r}\overline{30} \\
5 \\
\overline{-} \\
\overline{5} \\
\overline{-} \\
\overline{5} \\
10 \\
20\end{array}$ & \\
\hline $\begin{array}{l}1.3 .68 \\
7.3 .68\end{array}$ & $\begin{array}{l}2.0 \\
2.2\end{array}$ & - & - & $\begin{array}{l}\text { Clomiphene } 100 \mathrm{mg} / \text { day from } \\
21 \text { st February for } 28 \text { days }\end{array}$ \\
\hline $\begin{array}{r}6.5 .68 \\
21.5 .68\end{array}$ & $\begin{array}{l}2 \cdot 6 \\
3 \cdot 8\end{array}$ & $\overline{-}$ & $\overline{-}$ & \\
\hline
\end{tabular}

TABLE 5

SEMINAL ANALYSES FOR PATIENT D.G.

\begin{tabular}{|c|c|c|c|c|}
\hline Date & $\begin{array}{l}V o l \\
(m l)\end{array}$ & $\begin{array}{l}\text { Sperm count } \\
\left(\times 10^{6} / \mathrm{ml}\right)\end{array}$ & $\underset{(\%)}{M o t i l i t y}$ & \\
\hline $\begin{array}{r}7.8 .68 \\
14.8 .68 \\
21.8 .68 \\
26.2 .69\end{array}$ & $\begin{array}{l}1.0 \\
1.0 \\
1.0 \\
1.0\end{array}$ & $\begin{array}{l}1.0 \\
1.0 \\
4 \cdot 0 \\
1.0\end{array}$ & $\begin{array}{r}25 \\
5 \\
30 \\
10\end{array}$ & \\
\hline $\begin{array}{r}5.3 .69 \\
12.3 .69\end{array}$ & $\begin{array}{l}1.0 \\
1.0\end{array}$ & $\begin{array}{c}\text { Occasional } \\
2 \cdot 0\end{array}$ & $\begin{array}{c}\text { Few } \\
20\end{array}$ & $\begin{array}{l}\text { Clomiphene } 100 \mathrm{mg} / \text { day from } \\
27 \text { th February for } 14 \text { days }\end{array}$ \\
\hline 25.3 .69 & 1.0 & 1.0 & 50 & \\
\hline
\end{tabular}

After a similar finding in one case (A.W.) in 1965, numerous seminal analyses were arranged in all cases of Klinefelter's syndrome, with the resultant finding of four subjects showing motile spermatozoa in twenty-one out of forty-six ejaculates. As in Futterweit's patient, however, the biopsies of three of the cases showed no active spermatogenesis in the tubules observed in the section. 


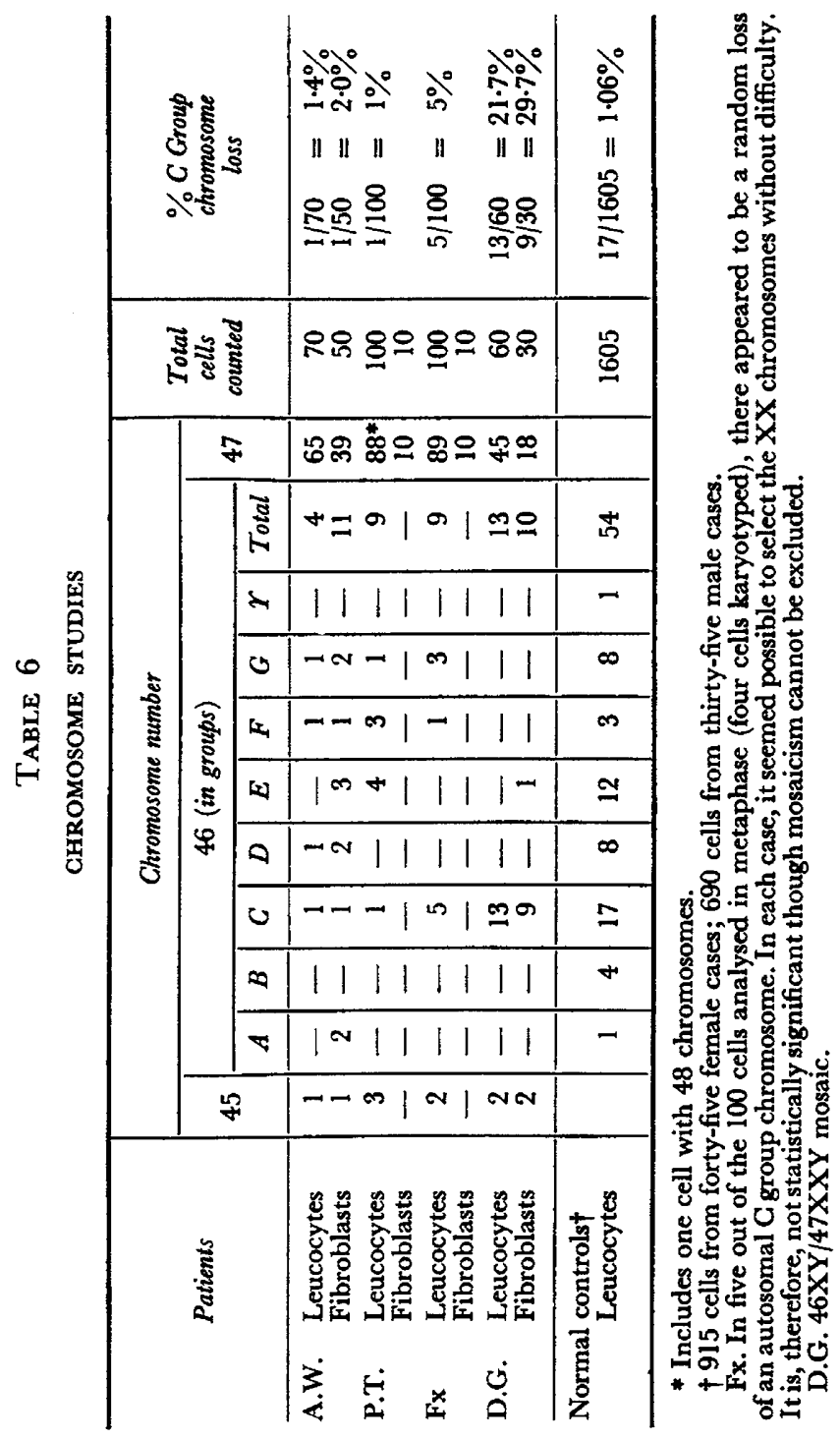




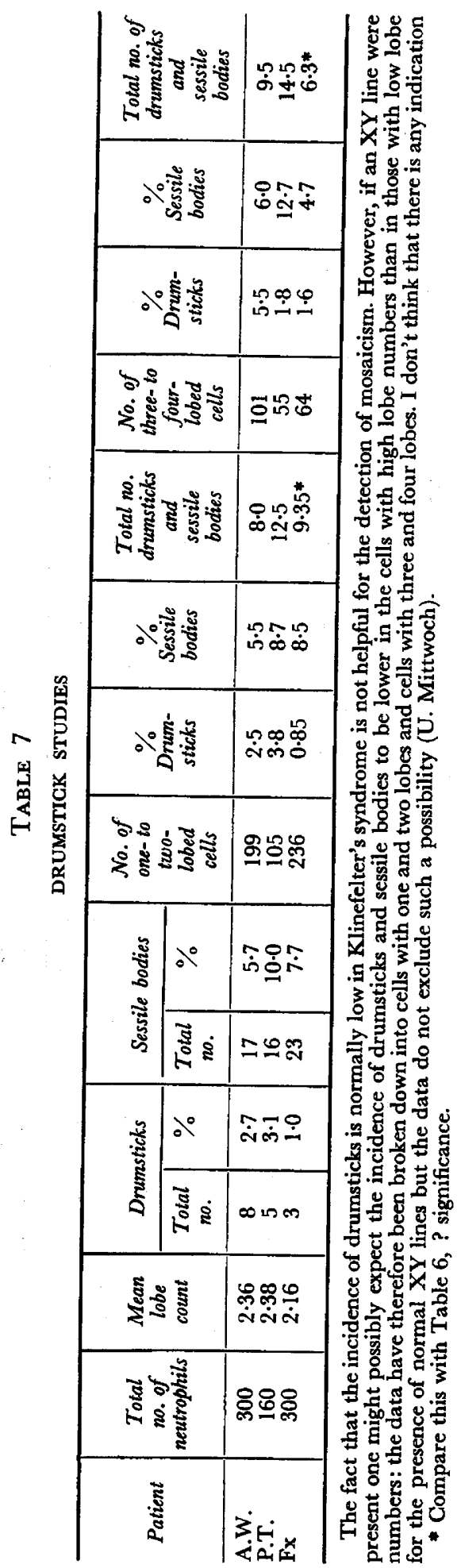


In the patient D.G., whose biopsy showed one tubule with full spermatogenesis, $47 \mathrm{XXY} / 46 \mathrm{XY}$ mosaicism was demonstrated in both leucocyte and fibroblast cultures (see Table 6). This was the only patient with motile spermatozoa in all seven ejaculates examined. The highest count recorded for this patient was $4 \times 10^{6}$ spermatozoa $/ \mathrm{ml}$ with $30 \%$ motility.

In the three cases with apparent $47 \mathrm{XXY}$ karyotypes, leucocyte drumstick patterns were analysed in blood films. No evidence of mosaicism could be found for two patients (A.W. and P.T.) but the findings were not so clear-cut in one patient (Fx) (see Tables 6 and 7), and mosaicism remains a possibility, although without statistical substantiation.

The problem lies in attempting to relate the findings of motile spermatozoa in the ejaculates of patients with Klinefelter's syndrome to mosaicism, as in the patient described by Warburg (1963) and in D.G. The cytogenetic studies carried out for patients A.W. and P.T. were extensive, and there is no reason to doubt that the abnormality arose in both cases before the formation of the zygote. It is, of course, impossible to exclude a minor $46 \mathrm{XY}$ line, such as might arise by the post-zygotic loss of an $\mathrm{X}$ chromosome in mitotic division. This could only be of importance if such a line were considered necessary for spermatogenesis with motile spermatozoa.

The patient P.T. on one occasion had a count of $24 \times 10^{6}$ spermatozoa $/ \mathrm{ml}$, with $50 \%$ motility. This raises the question of possible fertility in such a male. Warburg (1963) claimed that his Klinefelter patient with a $47 \mathrm{XXY} / 46 \mathrm{XY}$ mosaicism was the likely father of two sons. Kaplan, Aspillaga, Shelley \& Gardner (1963) also reported a man of 70 years with a 47XXY karyotype (blood culture only), who claimed to be the father of seven children by three wives, but, no doubt because of his age, no seminal studies were conducted, and his progeny were not available for blood typing. In a personal communication to Kaplan et al. (1963), Frøland and Ulrich also claimed "apparent fertility" in a man with 47XXY sex chromosome constitution. However, Lennox (1963) found, in four such instances, that children believed to have been sired by their father were adopted in two, and that blood group studies disproved paternity in the other two.

In the future, with the aid of storage in liquid nitrogen of several semen specimens, and subsequent concentration of the sperm population, it may be possible by artificial insemination to achieve proven parenthood in Klinefelter's syndrome.

After 27 years, the picture of Klinefelter's syndrome has been modified and the concept of hopeless sterility may also have to be changed. The only definite characteristics of this syndrome are small testes, not larger than $2.5 \mathrm{ml}$ in volume, showing varying degrees of tubular fibrosis with Leydig cell hyperplasia.

\section{ACKNOWLEDGMENTS}

Our thanks are due to the Staff of the Cytogenics Laboratory, Southmead Hospital, Bristol, to Dr Ursula Mittwoch for the drumstick studies, to Dr Shirley Richmond for valuable assistance, to the Department of Pathology, 
University of Bristol, for microphotographs, and to the Ethel Showering Research Fund for financial assistance. The invaluable cooperation of $\mathrm{Dr}$ Loraine and his colleagues is much appreciated.

\section{REFERENCES}

Adamopoulos, D. A., Loraine, J. A., Ismail, A. A. A. \& Foss, G. L. (1971) Endocrinological studies in patients with Klinefelter's syndrome treated with clomiphene. F. Reprod. Fert. 25, 409.

Foss, G. L. (1968) Testicular biopsy. In: Biopsy Procedures in Clinical Medicine, Chap. 14, p. 161. Ed. A. E. Read. John Wright, Bristol.

Foss, G. L., Bell, E. T., Lewis, F.J. W., Loraine, J. A. \& Pollard, B. R. (1967) Effect of clomiphene on spermatogenesis and hormone excretion in a patient with Klinefelter's syndrome. $\mathcal{J}$. Reprod. Fert. 13, 315.

FutTerwert, W. (1967) Spermatozoa in seminal fluid of a patient with Klinefelter's syndrome. Fert. Steril. 18, 492.

Kaplan, H., Aspillaga, M., Shelley, T. F. \& Gardner, L. I. (1963) Possible fertility in Klinefelter's syndrome. Lancet, i, 506.

Klinefelter, J. F., Reipenstein, C. E. \& Albright, T. F. (1942) Syndrome characterized by gynaecomastia, aspermatogenesis without a-Leydigism and increased secretion of follicle stimulating hormone. 7. clin. Endocr. Metab. 2, 615.

Lennox, B. (1963) Possible fertility in Klinefelter's syndrome. Lancet, i, 611.

Moorhead, P. S., Nowell, P. C., Mellman, W. J., Battips, D. M. \& Hungerford, D. A. (1960) Chromosome preparations of leucocytes cultured from human peripheral blood. Expl Cell Res. $20,613$.

Steinberger, E., Smith, K. D. \& Perloff, W. H. (1965) Spermatogenesis in Klinefelter's syndrome. 7. clin. Endocr. Metab. 25, 1325.

Warburg, E. (1963) A fertile patient with Klinefelter's syndrome. Acto endocr., Copenh. 43, 12. 